\title{
SOCIAL LEARNING-BASED O2O MODEL FOR INNOVATIVE INFORMATION DIFFUSION
}

\section{$\operatorname{Bin} \mathrm{Du}$}

Original scientific paper According to cognitive theory of social learning and information fusion between online and offline of consumer network, this paper constructs two-stage social learning (TSSL) model and online to offline or offline to online $(\mathrm{O} 2 \mathrm{O})$ learning model to explore the diffusion law under the condition of multilevel cascade network. Innovative information diffusion model based on social learning makes up defects of traditional innovation diffusion model with time and emerges simulation method of social network. Empirical research shows that information diffusion which is based on the consumer network fits sample data better. Social learning effect plays a key role in the book publish diffusion. Research results show that it is beneficial to explore essence of the innovative product information diffusion and design targeted strategies in electronic commerce market.

Keywords: information diffusion; innovation; offline; online; social learning

Model 020 za širenje inovativnih informacija utemeljen na socijalnom učenju

Izvorni znanstveni članak

U skladu s kognitivnom teorijom socijalnog učenja i povezivanja informacija između online i offline mreže potrošača, u radu je konstruiran model socijalnog učenja s dva stupnja - two-stage social learning (TSSL) i online - offline ili offline - online (O2O) model učenja za istraživanje zakona o širenju informacija u kaskadnoj mreži s više razina. Inovativni model za širenje informacija utemeljen na socijalnom učenju popravlja nedostatke tradicionalnog modela za širenje informacija po kojem će se informacije s vremenom same proširiti i postavlja simulacijsku metodu društvene mreže. Empirijskim se istraživanjem pokazalo da širenje informacija utemeljeno na mreži potrošača bolje odgovara uzorkovanim podacima. Učinak socijalnog učenja ima ključnu ulogu u širenju informacija o objavljenim knjigama. Rezultati istraživanja pokazuju da je korisno istraživati bit širenja informacija o inovativnom proizvodu te izraditi odgovarajuće strategije na elektroničkom tržištu proizvoda.

Ključne riječi: inovacija; offline; online; socijalno učenje; širenje informacija

\section{Introduction}

The rational people have their own viewpoint or belief to most things in the real world [1]. The formation and evolution of this viewpoint and belief are based on information related to these things and results of series learning by the way of observing the behaviour of other individuals for one rational individual. The learning process is called social learning $[2,3]$. There are many ways to obtain information and observe others' behaviour in the network era for the individual. These ways can be divided into two categories, online and offline. By the way of online mode, this paper can release product information, buyer comments, purchase order, customer service consulting $[4,5]$. By the other way of offline mode, we can observe quality and function of the product, exchange attainment and idea, experience ourselves $[4,6]$. These network structures of online and offline stack one complex social network, and the bounded rational economic man in the complex social network turns into social man [7].

Innovation diffusion refers to the spread procedure of innovation products in whole or local social group members through certain channels after some time. When consumers verify that the new product is superior to the old one, the innovation knowledge is gradually spread by the approach of learning by observing [8]. The diffusion process will experience a certain amount of time. The adopted behaviour usually will be delay, and consumers will not adopt innovation at the same time. Innovation adoption with different time results in the diffusion process in the consumer levels. The adoption of innovative products follows curve law [9]. At the beginning few consumers adopt, then the others obtain the information and adopt it too. In the adoption process, it is accelerated on the start stage. But the adoption quantity achieves a certain degree or saturation state, the adoption speed will reduce finally. The widely accepted theory is mainly Bass model. From 1960s in the earliest, Bass combined some theories which are raised by Fourt, Woodlock and Mansfield [9, 10]. These suppose that new product's potential adoption will be affected by the transmission of S shape curve or bell curve, and have not been unified for the connotation analysis of the curve shape. Scholars put forward many Bass derivative models to make up Bass model's deficiency, such as quadratic interval [11], advertising effect [12], energy system [13], digital divide [14], short life cycle [15], time-varying and dot parameters [16]. These derivative models relax the basic assumptions of Bass model, and they consider more realistic factors, so as to improve the explanation ability and the prediction ability of the model.

The essence of the innovation product's diffusion is that a large number of potential consumers' microscopic adoption behaviour centralizes to macro level patterns. For information technology develops promptly, potential consumers' micro adoption behaviours not only embody the independent of individual, but also can be affected by the network structure of the consumers. Bass model recessively supposes that potential consumer network of innovative products is connected completely, that is any two consumers in the network know each other, and influence to the consumer adoption behaviour from the other individual consumer in the social network is equal. It is similar to the disease spread in the crowd, as long as the consumer contacts with the adopted person, he will certainly adopt this innovative product. The above Bass class model's implicit assumptions of potential consumers network stay on the theoretical level. Actual social network is very low probability as rule network. 
However, Bass model class has one certain gap with the real world.

In recent years, a large number of scholars explore some problems related to consumer network and information diffusion from the perspective of complex network. Paul Dwyer thought that consumer network was different from terrorists or technical network which would never be attacked. Message boards, chat rooms, blogs and virtual communities could constitute a consumer network, which contains social and information features, and would evolve under reputation effect over time [17]. Young analysed new belief and product diffusion process in heterogeneous potential consumer network to construct infection, social influence and social learning models and deeply depicted the variation characteristics of consumers adopt curve [18]. At last, he made empirical analysis to information diffusion mechanism by the way of Tyan and Gross' classical methods. Christine and Martin used the spread of virus replication as social network marketing way to increase brand awareness [19]. This was similar to morbid spread of computer virus, so the marketing method could quickly get a large number of customers. Peres, Muller and Mahajan thought the diffusion process of new products and services had complex and hierarchy [20]. Consumers could receive all kinds of the influence of various sources, such as words of mouth, network externality and social signal. Consumer network was one outcome of a variety of environment to depict influence effect of information diffusion in complicated network environment through diffusion life cycle.

This paper on information diffusion models which is based on the consumer network, with potential consumer network as the starting point, reflects network structure parameters in diffusion over time and uses real innovation adoption diffusion data to fit the model [20]. Different from the simulation research based on the complicated social network, this study method does not forecast by supposing the consumer network structure but by realistic diffusion data. Therefore, the information diffusion model based on consumer network combined advantages of the two research methods, and overcame the defects without empirical data.

\section{Literature review}

There are many different concepts and classifications on innovation diffusion in the academic field. Among them, the innovation diffusion theory proposed by Rogers is more widely accepted. Rogers believes innovation covers a broad range of content, including new technologies, new products, new management system, etc. Innovation diffusion has four elements as innovation, channel, time and social system members. Potential individual or organization consumers to adopt the innovation decision process conform to five stages model [21]. Five stages model by Rogers in the innovationdecision process and attributes of innovation theory served as the theoretical base for the study.

With the in-depth study of innovation diffusion field, diffusion model was constructed to predict the future trend of the innovation diffusion, so as to provide decision support for innovation management [22]. It has become the focus of scholars for a long time. According to the adopters of homogeneity or heterogeneity, the diffusion model is divided into three categories.

\subsection{Infectious disease model}

Mansfield is one of the early scholars to research innovation diffusion model. Combined with the infectious disease principle and the growth curve, he proposed the $\mathrm{S}$ diffusion model in 1961 [23]. It is a beginning to study diffusion problem by macroscopic quantitative analysis system. But implicit assumption of Mansfield model is homogeneous in the social system. Bass considered that the potential adopter is different. Infectious diseases premise of the Bass model apparently does not conform to the reality [24]. Subsequent researchers have been trying to break through the Bass model framework putting forward many new models, mainly divided into two categories as individual level model and overall level model.

\subsection{Individual level model}

Individual level model is one substitution model of Bass model class. The premise is that consumers do not adopt products immediately after the access to information. With the diffusion of innovative information, consumers can obtain lower uncertain information, maximize the utility and choose to maximize revenue product. In view of the influence factors of mass media on innovation acceptance of the potential adopter, Mahajan and Schoeman built external influence model of innovation diffusion [25]. Chatterjee model and others point out that consumers are risk averse. Only when the expectation exceeds the risk threshold or price threshold, they will adopt a new product [26]. According to positive or negative information update expectation, consumers are heterogeneous [27]. Song and others consider the heterogeneity, observe the behaviour of consumers and adopt the overall sales data rather than the subjective data obtained from the survey to estimate model [28].

\subsection{Overall level model}

Overall level model provides macroscopic description of innovation diffusion over time. Based on micro decision theory, Duan et al. established a single potential user decision model under the condition of certainty and uncertainty, and further extended to the macro level model [29]. Bemmaor and Lee deduced overall level diffusion model from the individual heterogeneity hypothesis, through forecast sales of 12 kinds of new products, and found that the model has higher predictive power than the Bass model [30]. Wang and Sun analysed the adoption behaviour of consumers to replace part of new products, then proposed non replace market diffusion model by diffusion concept and new parameters [31].

Jing analysed 20 e-commerce websites and found that the traditional information service providers have not mined the user's long-term information demand and formed user's interest descriptive model. Then it is not active to push customized information for the user and is difficult to improve user satisfaction degree of the information service [19]. The limitations of information 
overload and information passive service mode result in separated $\mathrm{O} 2 \mathrm{O}$. $\mathrm{O} 2 \mathrm{O}$ is a novel mode of electronic commerce and fuses online virtual integration service and offline entity experience [8]. It is aroused by the scholars and the business community's concern, becoming a hot issue in the research of mobile commerce. Based on the perspective of cognition, $\mathrm{O} 2 \mathrm{O}$ mode is the electronic commerce enterprise to provide the multi-dimensional social learning platform across network for the user.

Zhong and other scholars, using case study method to study China's high technology enterprise cross network boundary learning, discovery learning acquisition of cross network knowledge, is mostly restricted to learn knowledge within internal network [32]. Lai collected 179 copies of questionnaires, such as seven enterprise network how to break through the risk, knowledge learning and reputation across network boundaries, and provides new research view for domestic enterprises by learning to achieve a successful transition and high-end breakthrough [33]. At present, based on the diffusion of innovation across the network social learning research results are fewer.

\section{Consumer network structure}

Bounded rational social people have two kinds of drive way about information diffusion. One is the endogenous study way, through the common knowledge to observe the product quality or experience the service function of offline product personally. The other is exogenous study way, such as social media advertising sponsored by manufacturers, which is the direct learning material that innovation enterprise provides to the consumer or reputation effect as consumers get information through social relationship to produce learning effect.

This paper describes the complicated consumer network with the graph. Node means individual consumer, such as individual, enterprise, etc. The side of nodes means interactive relationship between individuals. $G(V$, $E)$ presents consumer network. The consumer set $V$ contains $N$ individuals. Edges of individuals form set $E$. All sides are undirected. For example, the learning effect between the consumers is mutual, and there is only one edge between any two nodes.

1) The edge number $k_{i}$ of node $i$ in the network is called degree of the node. It means that the individual consumer has the quantity of the learning ways.

2) The minimum edge number between any two nodes $(i, j)$ in the network is called the shortest path of $(i$, $j)$. The average value of the shortest path is the network average shortest path.

3 ) Supposing the set of connected nodes of node $i$ is called $\Phi_{i} . \Phi_{i}$ has the highest edge number which is $k_{i}\left(k_{i}-1\right) / 2$. Actually, the ratio between the number of edge and the highest edge number is called aggregation coefficient of node $i$. All nodes average aggregation coefficient in the network is called the network average aggregation coefficient.

Every two nodes in random network are linked together with a certain probability, have a small average aggregation coefficient and average shortest distance. In recent years, through a large number of social network's empirical studies [20], researchers found that social network is neither rule network nor random network completely. A kind of network has large average aggregation coefficient and smaller average shortest path, which contains small world characteristics. Watts and Strogatz proposed one method to construct small world network, a model called WS [34]. In another type network few nodes have a large degree. Most of the nodes have smaller degree. Degree of these nodes obeys the distribution of power law. Connect degree of internet, www and other network's nodes obey the distribution of law. This network's nodes have no obvious characteristic length, which is called the scale-free network. Barabasi proposed the construct of a scale-free network model, which has the growth characteristics and priority connection characteristics [35]. The new node tends to link the node with high connection degree. This is called rich get richer phenomenon or Matthew effect, as new literature tends to quote the literature which is widely used. Scale-free consumer network is the superposition of the multiple social networks. Every node has many kinds of neighbour nodes. Node and neighbour nodes belong to one faction. They have close relation and common neighbour nodes. Node and the new neighbour node belong to different faction, whose connection is random. In the reality, according to the interactive frequency and degree, every consumer has a different type of interpersonal social relations. Some interpersonal relationship is relatively close, and some relationships are general. So the scale-free consumer network can reflect the strength of interpersonal relations in the reality by different network neighbour nodes.

The consumer in the real world is intelligent individual with independent learning, through the network online and offline. He will form microscopic belief by social learning effect, which is the decision-making behaviour of adopting or not adopting. Therefore, consumer network is multi-level cascade, which is one kind of complex social network with the interaction function and multiple effects of online or offline.

\section{Diffusion models}

\subsection{Basic model}

Assumptions of basic model are as follows. Two consumers who know each other in the network do not necessarily exchange information on innovation. Though there is communication on the innovation information between the adopters and the non-adopters who know each other, the non-adopters will not necessarily adopt innovation. In each adopted period $t$, each non-adopter has only one opportunity to communicate, and this can control the length of time of the adoption cycle to satisfy this condition [38].

The consumer network faced by information diffusion contains $N$ potential consumers which is constant. $n_{t}$ means the number of the adopters in the period $t . N_{t}$ means the cumulative number of adoption in the period $t . X_{i t}$ is a $0 \div 1$ variable. It means the adoption situation in the period $t . X_{i t}=0$ means consumer is in the situation of non-adoption in the period $t . X_{i t}=1$ means consumer is in the situation of adoption in the period $t$. 
In the early period $t$, the probability of the random selected consumer not adopted $P\left(X_{i t}=0\right)=\left(N-N_{t}\right) / N$. In the process of period $t$, the consumer who is faced with adopting decision has two learning channels of innovation information, i.e. endogenous learning and exogenous learning [39].The former depends on the consumer's public knowledge and experience, the latter depends on advertising and the communication with other consumers.

Assuming that the probability of the two channel information study is $\alpha$ and $1-\alpha$ conditional probability of adopting innovation for not adopted consumers $i$ under the influence of endogenous learning is $P\left(X_{i t}=1 \mid\right.$ Inlearning $)$ in the period $t$.

According to the third assumption, non-adopter only has one internal communication opportunity in each period. It will only make influence to his decision when his communication object is adopted by consumers, and its probability is $N_{t-1} /(N-1)$.

Probability of exogenous learning for non-adopter is $P($ Outlearning $)=(1-\alpha) N_{t-1} / N$, when $N$ is enough large. So $N$ approximately equals $N-1$. We can use $N$ instead of $N-1$ here.

Probability of adopted innovation under the influence of exogenous learning is $P\left(X_{i t}=1 \mid\right.$ Outlearning $)$. Therefore, probability of adopting innovation for the nonadopter $i$ is

$$
\begin{aligned}
& P\left(X_{i t}=1 \mid X_{i t}=0\right)=\alpha P\left(X_{i t}=1 \mid \text { Inlearning }\right)+ \\
& +(1-\alpha) P\left(X_{i t}=1 \mid \text { Outlearning }\right) N_{i t} / N=p+q N_{i t} / N
\end{aligned}
$$

among,

$$
\begin{aligned}
& p=\alpha P\left(X_{i t}=1 \mid \text { Inlearning }\right), \\
& q=(1-\alpha) P\left(X_{i t}=1 \mid \text { Outlearning }\right) .
\end{aligned}
$$$$
E\left[n_{t}\right]=\left(N-N_{t-1}\right)\left(p+q N_{t-1} / N\right) .
$$

From the perspective of network consumers, basic model can be interpreted as a fully connected rule network. The non-adopter's adopting decision is under the function of exogenous learning and endogenous learning in each period. The advantage of basic model is that Eq. (1) is full probability equation. So basic model has mathematics theory foundation, and we can use Bayesian learning to explore the law of information diffusion. The defect is that the model does not consider social influence variables, competition and cooperation, and other factors. So the basic model does not match the actual situation.

\subsection{Two stages social learning model}

In the real world, bounded rational consumer chooses whether or not to accept the innovation under the function of endogenous learning and exogenous learning. The process of the adoption decision can be divided into two stages. In the first stage, the crazy consumer who has no certain information chooses the adoption immediately. For example, as iPhone $4 \mathrm{~S}$ just appeared in the national market, consumers bought it after waiting in overnight queue. In the second stage, the inert or calm type consumers adopt sequential decision-making behaviour by observing to get certain information [4], so that a part of the consumers chose to buy iPhone $4 \mathrm{~S}$ when iPhone 5 appeared and iPhone $4 \mathrm{~S}$ is on sale. First consumers have heterogeneous values $\mathrm{v}$ and public knowledge $F, v$ obeys the distribution $F$.

Assuming the marginal cost of innovative products is $p$, in first stage adopted consumer ratio is $\beta(0 \leq \beta \leq 1)$, and there is $1-\beta$ ratio potential consumers in second stage. $s$ means the endogenous learning strength of product, and $0 \leq s \leq 1$. There are $n=\beta+(1-\beta) \beta s$ consumers who have adoption behaviour in two stages. When $\beta=1$, it means all of the consumers choose to buy the innovation product in first stage. When $\beta=0$, it means there is no consumer to buy products in first stage. Consumers can't realize social learning in second stage, and finally lead to no one buying any product, then $n=0$. When innovation products appear in the ordinary circumstances, some consumer will be the first one who is called "eat crabs", and $\beta>0$. Other consumers observe or study the behaviour of the first adopter. It indicates innovation is under diffusion with a certain speed. Diffusion velocity is decided by $s$.

When $p \leq c$ or $v<p$, manufacturers got no profit or consumers found the products value is lower than the price through social learning. There is no buy faith, so these won't produce trading. For the sake of simplicity, this paper does not consider these cases.

When $v \geq p>c$, consumers would like to buy and manufacturers would like to sell. In this case, the total adopters in period $t=1$ are $n_{1}=N \beta$. The total adopters is $n_{t}=n_{t-1}+\left(N-n_{t-1}\right) s \beta=N s \beta+(1-\beta s) n_{t-1}$. So

$$
\begin{aligned}
& N_{t}=\frac{1}{\beta S}\left[N \beta+N \beta s(t+1)-(1-\beta s) n_{t}\right], \\
& E\left[n_{t}\right]=\frac{N \beta}{1-\beta S}[1+s(t-1)]-\frac{\beta s}{1-\beta s} N_{t} .
\end{aligned}
$$

Through estimating the parameter $\beta$ and $s$, we can understand the influence of the non-adopter under the number and the learning intensity of the adopters. Therefore, TSSL model can easily present the information diffusion's social learning mechanism. The main differences between TSSL model and Bass are as follows. (1) On TSSL model, every consumer has $\beta$ adopters in the former stage. (2) Every non-adopter has s learning strength, it will affect the decision behaviour about innovation adoption, but Bass model supposes there is only one adopter to affect the consumer's adoption decision on each stage. Therefore, TSSL model matches the reality better than Bass model.

\subsection{Online to offline or offline to online $(020)$ learning model}

In TSSL model, it is considered that consumers may cause social learning effect according to their own public knowledge or experience, and the social media or the influence of other adopters, but they did not distinguish these social influence source (online or offline). The influence of the interpersonal network source may occur in offline social network or in the online Internet network, such as some consumers observe the product design to experience products offline, and they consult service, place an order to buy the products online; some 
consumers Schedule to inspecting a house online, queue to buy houses offline etc. In order to distinguish different impact source, the differences of online and offline learning strength cause learning effect to be different, assuming $s_{1}$ means the learning strength offline, $s_{2}$ means the learning strength online. Assuming that the relationship between the combined influence and the number of the adopters is $y$, then $y=1-\mathrm{e}^{-\beta s_{2}}$. The $s_{2}$ is greater than 0 . It is said that consumers come with the ratio of the adopters, and the speed of the increase will get slow. To simplify, every consumer has the online and offline learning strength in the network. Then Eq. (4) can further be rewritten as

$$
\begin{aligned}
& E\left[n_{t}\right]=\frac{N \beta}{1-\beta s_{1}}\left[1+s_{1}(t-1)\right]-\frac{\beta s_{1}}{1-\beta s_{1}} N_{t}+ \\
& +\left(1-\mathrm{e}^{-\beta s_{2}}\right)\left(N-N_{t-1}\right) \frac{N_{t-1}}{N} .
\end{aligned}
$$

Based on the scale-free consumer network, $\mathrm{O} 2 \mathrm{O}$ diffusion model will import network topology structure parameter to innovation diffusion over time model, and judge potential consumer network characteristics. TSSL is a time series model from longitudinal perspective, but $\mathrm{O} 2 \mathrm{O}$ is designed from horizontal perspective. Enterprise can make full use of estimated potential consumer network structure and the characteristic information to promote innovative product successfully.

\section{Empirical research}

Based on basic model, TSSL model and O2O model of consumer network, this paper chooses $21^{\text {st }}$ Century Press as data sample based on two reasons. One is abundant information, integrated data structure and usability of data format. The other is convenience and accuracy of data acquisition.

\subsection{Sample description}

No matter paper media or electronic media, book is the carrier of information and knowledge. The issue of book has a spread or communication effect. Sample attribute is divided into two kinds. One is book category. The other is issue channel. These books have nine categories, such as Enlightenment books (Eb), Children
Literature $(\mathrm{CL})$, Cartoon books $(\mathrm{Cb})$, Youth Reading (YR), Popular Science books for youth (PS), Picture books $(\mathrm{Pb})$, Culture and Education $(\mathrm{CE})$, Educational Games (EG), Mass Reading (MR). Distribution channels have traditional offline bookstores, such as Xinhua bookstore, private bookstore, etc. online bookstore (such as Dangdang, Amazon website, etc.) and individual operators with mixed channels about online or offline.

\subsection{Parameter estimation}

To estimate basic model, TSSL model and O2O model, this paper uses data that is nine categories and three channels of book cumulative circulation. Parameter values of mode are evaluated by Eq. (1), Eq. (3), and Eq. (4) respectively. $E\left(n_{t}\right)$ in the model is calculated by $N_{t}-$ $N_{t-1}$, which is the increment of book accumulated circulation in relation to the accumulation of last year. Eq. (5) is estimated with ordinary least squares after the linearization. This calculates parameters $N, p$ and $q$ after estimation of these coefficients by $E\left(n_{t}\right)=p N+(q-p) N_{t-1}-(q / N) N_{t-1}^{2}$. Before estimation of TSSL and O2O model, assuming that the number of potential consumers is exogenous variable and it is estimated by Eq. (2). Traditional estimation of nonlinear equation method is nonlinear least squares or sequential quadratic programming. From the viewpoint of theory and empiric, parameter estimation methods of information diffusion model are compared in the aspects of the parameter estimation's unbiasedness and systematic error and so on. Genetic algorithm is better than nonlinear least squares, Kalman filtering, Bayesian method, and other parameter estimation methods.

This paper uses genetic algorithm to estimate TSSL and $\mathrm{O} 2 \mathrm{O}$ model. The fitness function is $S S E=\sum\left(n_{t}-\hat{n}_{t}\right)^{2} \cdot \hat{n}_{t}$ is the number of adopter of model estimation in period $t$. $n_{t}$ is the actual number of adoption in period $t$. T is the total number of time. By using the minimize fitness function to estimate parameters, the specific operation is computed by genetic algorithm toolbox of Matlab2010b. For further analysis, as for TSSL and $\mathrm{O} 2 \mathrm{O}$ model, nonlinear regression of the asymptotic $\mathrm{F}$ distribution statistics is of significance to test parameters. These models' parameter estimation values can be seen in Tab. 1 .

\begin{tabular}{|c|c|c|c|c|c|c|c|c|}
\hline \multirow{2}{*}{ Item } & \multirow{2}{*}{$N$} & \multicolumn{2}{|c|}{ Basic model } & \multicolumn{2}{|c|}{ TSSL model } & \multicolumn{3}{|c|}{$\mathrm{O} 2 \mathrm{O}$ model } \\
\hline & & $p$ & $q$ & $\beta$ & $S$ & $\beta$ & $s_{1}$ & $s_{2}$ \\
\hline $\mathrm{Eb}$ & $1,9 \mathrm{e}+08$ & 0,0197 & 0,7545 & 0,8147 & 0,6557 & 0,8147 & 0,6197 & 0,4387 \\
\hline $\mathrm{CL}$ & $1,1 \mathrm{e}+08$ & 0,0165 & 0,4217 & 0,9084 & 0,0836 & 0,7989 & 0,2807 & 0,5068 \\
\hline $\mathrm{Cb}$ & $3,2 \mathrm{e}+07$ & 0,0190 & 0,5170 & 0,8367 & 0,6724 & 0,2517 & 0,5583 & 0,2087 \\
\hline YR & $9,7 e+07$ & 0,0168 & 0,8081 & 0,1998 & 0,9746 & 0,5936 & 0,2909 & 0,7262 \\
\hline PS & $5,6 e+07$ & 0,0162 & 0,5087 & 0,3762 & 0,0684 & 0,7831 & 0,7569 & 0,5920 \\
\hline $\mathrm{Pb}$ & $3,5 e+07$ & 0,0017 & 0,5870 & 0,6308 & 0,0587 & 0,5501 & 0,1976 & 0,2500 \\
\hline $\mathrm{CE}$ & $2,0 \mathrm{e}+08$ & 0,0139 & 0,0866 & 0,2495 & 0,1030 & 0,1079 & 0,0100 & 0,8300 \\
\hline EG & $1,3 \mathrm{e}+08$ & 0,0227 & 0,3607 & 0,3893 & 0,6365 & 0,3439 & 0,6463 & 0,0861 \\
\hline MR & $2,2 \mathrm{e}+07$ & 0,0290 & 0,4677 & 0,3511 & 0,9712 & 0,5139 & 0,0650 & 0,5968 \\
\hline offline & $7,0 \mathrm{e}+07$ & 0,0003 & 0,9317 & 0,5888 & 0,5642 & 0,0205 & 0,8518 & 0,0418 \\
\hline mixed & $1,7 e+08$ & $-0,0006$ & 0,9832 & 0,2954 & 0,1034 & 0,0424 & 0,5814 & 0,6194 \\
\hline online & $5,5 e+07$ & $-0,0004$ & 0,9868 & 0,0539 & 0,6110 & 0,1505 & 0,3085 & 0,9648 \\
\hline
\end{tabular}

Table 1 Parameter estimation values of three models 


\subsection{Analysis}

\subsubsection{Comparison of fitting validity}

To compare the fitting degree of the various models with sample data, this paper introduces equation of modified goodness of fit. Tab. 2 shows the correction $\mathrm{R}^{2}$ of estimating equations. Seen from Tab. 2, TSSL and $\mathrm{O} 2 \mathrm{O}$ model are better than basic model for data fitting validity. TSSL and $\mathrm{O} 2 \mathrm{O}$ model are closer to express diffusion trend of real world. They have more explanatory power than the basic model. TSSL model is better than $\mathrm{O} 2 \mathrm{O}$ model on fitting validity. It may be that sample study period is short and the online and offline data is not accurate or the discrimination is not enough, such as individual data is merely comprehensive to online data and offline data, rather than distinguishing the two data strictly, so it can't present the advantage of $\mathrm{O} 2 \mathrm{O}$ model. Average correction goodness of fit of TSSL and $\mathrm{O} 2 \mathrm{O}$ model reaches 0,79 and 0,75 respectively for nine books products and three kinds of marketing channel diffusion data. Therefore, TSSL and $\mathrm{O} 2 \mathrm{O}$ model can better fit the issue of the diffusion effect on the whole.

Table 2 Fitting effect

\begin{tabular}{|c|c|c|c|}
\hline \multicolumn{4}{|c|}{ Table 2 Fitting effect } \\
\hline$R^{2}$ & Basic model & TSSL model & O2O model \\
\hline $\mathrm{Eb}$ & 0,41 & 0,46 & 0,33 \\
\hline $\mathrm{Cb}$ & 0,87 & 0,93 & 0,95 \\
\hline $\mathrm{YR}$ & 0,52 & 0,62 & 0,58 \\
\hline $\mathrm{PS}$ & 0,8 & 0,75 & 0,63 \\
\hline $\mathrm{Pb}$ & 0,91 & 0,9 & 0,86 \\
\hline $\mathrm{CE}$ & 0,45 & 0,69 & 0,71 \\
\hline $\mathrm{EG}$ & 0,89 & 0,85 & 0,92 \\
\hline $\mathrm{MR}$ & 0,46 & 0,64 & 0,55 \\
\hline offline & 0,64 & 0,96 & 0,89 \\
\hline mixed & 0,43 & 0,87 & 0,83 \\
\hline online & 0,81 & 0,85 & 0,82 \\
\hline Average & 0,65 & 0,91 & 0,92 \\
\hline
\end{tabular}

\subsubsection{Social learning effect}

Social learning including exogenesis learning and endogenous learning drives the innovation products to diffusion commonly in potential consumers, such as book issuance and video album release, interpersonal interaction, etc. Exogenesis learning represents that consumers accept the diffusion effect of the media advertising. Endogenous learning represents the reputation effect of consumers.

Variables $p$ and $q$ in the basic model represent strength coefficient of exogenesis learning and endogenous learning for all kinds of diffusion. There are 0,0129 and 0,6187 from Tab 1 . The study strength coefficient of TSSL model and $\mathrm{O} 2 \mathrm{O}$ model is given by Eq (4) and Eq. (5), and they vary as the time changes. According to data in Tab. 1, Fig. 1 reveals the law that learning strength of books $(\mathrm{CL}, \mathrm{Cb}, \mathrm{MR}$ and three channels) varies over time. Learning strength of other types of books is similar to Fig.1, so they are omitted. From Fig. 1, along with the increment of potential consumers, after 1 or 2 periods, the number of the adopter reaches saturation. Meanwhile, learning strength began to abate in a downward trend, and presents a unimodal form. Learning strength is in the process of decline, but does not tend to 0 . It shows that there still exist a few adoption behaviours of consumers. This verifies the view that knowledge is never out of date. It can be seen from Fig. $1 \mathrm{~d}$, in the initial stage of diffusion, learning strength of offline and mixed is greater, meanwhile learning strength of online is smaller. After 1 or 2 periods, learning strength of online channel is greater than one of the mixed and offline. Mixed channel is in the centre. Offline channel is the lowest.
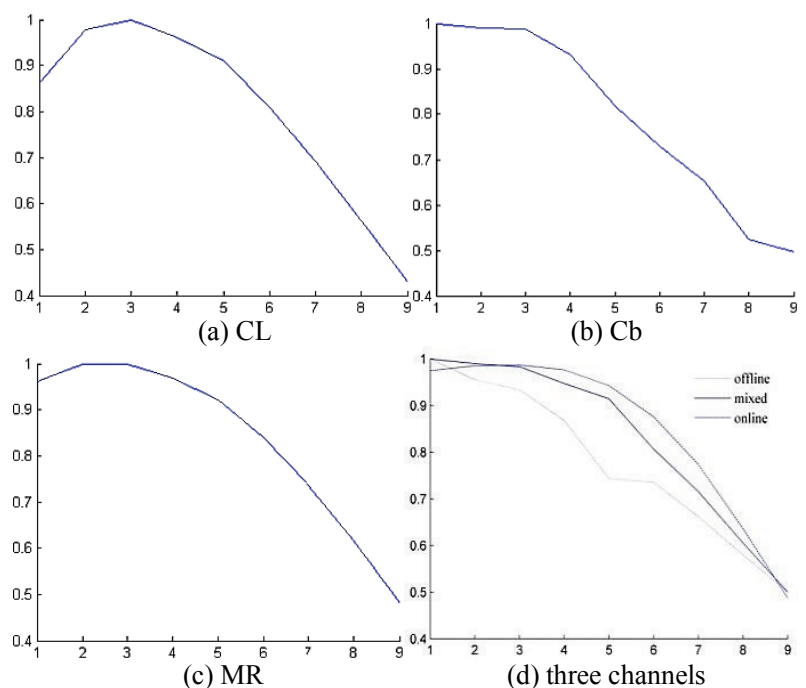

Figure 1 Social learning strength with time

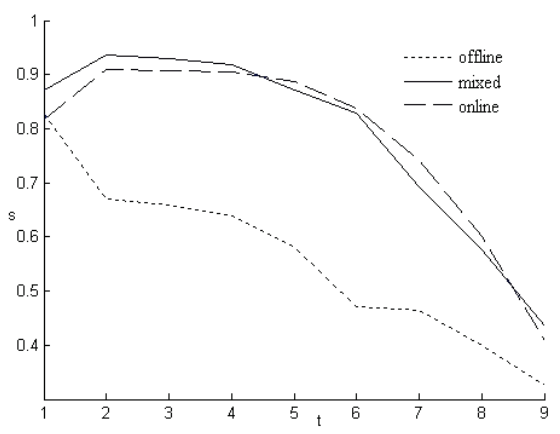

Figure 2 Online and offline learning strength

\subsubsection{Online and offline learning effect}

$\mathrm{O} 2 \mathrm{O}$ model describes consumer learning strength of offline or online channel and the trend of information diffusion. According to marketing channel classification, offline channels refer to the Xinhua bookstore, book house, supermarket shelves, etc. Online channel refers to bookstore websites, such as Dangdang, Amazon, etc. They are entirely online channels. Mixed channel refers to the individual operator's book issue. There are offline channels like store fronts and online channels like shops on the website. According to data in Tab. 1, it is shown that $s_{1}$ of offline channel is the maximum and $s_{2}$ is the minimum with only $0,0418 . s_{2}$ of online channel is the largest. $s_{1}$ and $s_{2}$ of mixed channel are middle. These results are consistent with reality. Seen from Fig. 2, the learning strength of mixed channel and online channel have a rise phase in early stage, but offline channel has been in the slack state, and it declines rapidly. It is thus clear that the online learning which is based on the Internet effect can promote the issuance and information diffusion, it is far bigger than offline learning strength, so 
the development of E-commerce is the inevitable choice of product information diffusion, different industry enterprise faced with the challenge from the network needs to change the traditional ideas, and make full use of social media and electronic business platform.

\subsubsection{Book consumer network}

According to complicated network model, we know that broken link rewiring probability $L$ means the consumer network's random degree. When $L$ is closer to 0 , it means that the network structure is closer to the rule network. When $L$ is closer to 1 , it means that the network structure is closer to the random network. When $L$ is between 0,001 and 0,1 , the network is small world network. TSSL model and $\mathrm{O} 2 \mathrm{O}$ model contain the parameters $L$ which reflect consumer network topology. The learning strength $\mathrm{s}$ presents the possibility of connection between the nodes, which is parameter $L$. In Tab. 1, we can get that consumer network which is faced by all kinds of books is slightly different. A few of consumer networks are small world networks, such as children literature, science popularization, picture book The others are mostly random networks. Newman [38] summarized some empirical research on the topological characteristics by a large number of social networks including film actor network, scientists, cooperation network in recent years. He found that these social networks are small world networks. Different from the other social network conclusions of empirical research, the books consumer network which is estimated by the TSSL model is not all small world network. Therefore, TSSL model can reveal the potential consumers' network structure of book distribution.

It is difficult to test consumer network topology characteristics by empirical research at present. This paper can apply TSSL model and $\mathrm{O} 2 \mathrm{O}$ model to predict consumer network topological characteristics for the reason that the same product has different characteristics in different types of consumer diffusion network. In the case that consumer network structure characteristics are known, innovation enterprise can implement some targeted marketing strategies.

\subsubsection{Online and offline influence mechanism}

In the $\mathrm{O} 2 \mathrm{O}$ model there is the relationship of consumer online learning strength and the proportion of adopter.

$S_{\text {online }}=1-\mathrm{e}^{-\beta s_{2}}, \beta$ is the proportion of adopter.

Fig. 3 shows the function relationship of consumer online learning strength and the proportion of adopter in the diffusion process of book products, including CL, Eb, offline channel, mixed channel and online channel. The rest of the books are similar to these. This paper can see the influence of law of adopter to non-adopter's decision in Fig. 3. The curve increases with the increment of the adopter proportion, and the increasing speed is firstly fast, then slow.

Comparing book issue data, the differences of adopter proportion are large to make social learning strength to be the maximum. The maximum is from online channel about $43 \%$. The minimum from offline channel about $15 \%$. Taken together, non-adopters are easy to be affected by the adopters in the process of adoption decision. In the interpersonal relationship, the small proportion acquaintance's adoption decision will make great influence from trustful adoption.

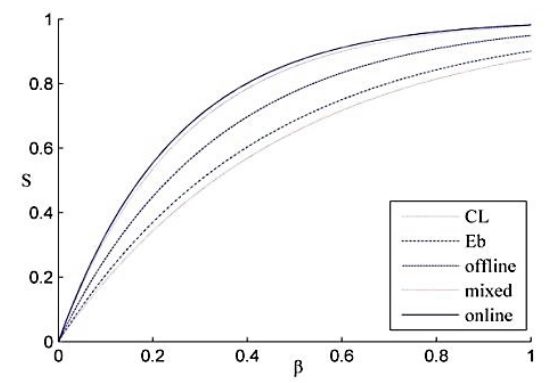

Figure 3 Relationships between learning strength and adopters

\subsubsection{Online and offline learning strength}

In $\mathrm{O} 2 \mathrm{O}$ model, variable $s_{1}$ and $s_{2}$ express the learning impact strength of consumer adoption decision-making. The impact of social learning will vary with the adoption period. The average learning impact strength of book distribution is $s$ in the period of sample study period. From nine different species, the offline impact strength of $\mathrm{Pb}$ is very small, but the online learning strength is greater. So purchasing desire is greater after consumer has seen the picture from the screen or networks. Publishers should strengthen the marketing efforts of the online channel. CE is mainly fixed consumer groups, such as students in the school. So learning strength from offline is stronger and learning strength from online is lower. Seen from distribution channels, online learning strength from online channels is close to 1 . The offline learning strength from offline channel is larger. Learning strength of mixed channel is middle and integrated learning intensity is larger. In the diffusion data of book distribution, offline learning intensity strength and online learning strength are not greater (close to 1) or are small (close to 0) synchronously.

\section{Conclusion}

According to information fusion between consumers network structure and subject social cognitive learning, this paper constructs TSSL model and O2O model, and explores multi-level network overlay under the condition of diffusion regularity. The empirical results show that TSSL model and $\mathrm{O} 2 \mathrm{O}$ model are better than traditional Bass class models to depict diffusion phenomenon of the reality. Based on consumer network, these diffusion models test actual data and network factors, make up defects of traditional diffusion models and simulation methods from social network analysis. Applying real data of consumer network structure, this paper provides a new path to study diffusion problems under the background of big data. According to the issued book data by the empirical study, the following conclusions can be drawn.

Firstly, compared to basic model with unchanged endogenous learning parameters, TSSL model and O2O model are better to reveal dynamic learning strength of book distribution in the diffusion process. Offline factors 
and online factors of book products diffusion play jointly an important role. Although learning strength of different types and many distribution channels of books is different for consumers, results still inspire to book publishers some methods and creativity. For books marketing book publishers should emphasize diffusion law of heterogeneous consumer groups at different levels.

Secondly, $\mathrm{O} 2 \mathrm{O}$ model has flexible and diversified methods to reveal potential consumer network structure of the book distribution. Different empirical findings from other social network research, each consumer network of books are difference and not all small-world networks. Book publishers can develop targeted marketing strategies for structure characteristics of consumer network.

Lastly, TSSL and O2O model reveal social learning mechanism of innovation adopters. Different social mechanism influences peak time and level of innovation adoption, innovation diffusion speed and optimal marketing strategy of book products. The empirical results show that each book products consumer has different social learning mechanisms for adopted innovation. This paper proposes some marketing strategies under the conditions of the multi-level network overlay in the era of big data.

\section{Acknowledgements}

This work was partially supported by the National Natural Science Foundation of China (No. 71461011), Social Science Research Project of Jiangxi province of China (No. 14GJ29) and Jiangxi province visiting scholar special fund project funding for young teacher development plan at ordinary undergraduate university.

\section{References}

[1] Bandura, A. Social Cognitive Theory: An Agentic Perspective. // Annual Review of Psychology. 52, 1(2001), pp. 1-26. DOI: 10.1146/annurev.psych.52.1.1

[2] Bandura, A. Social Learning Theory. New York : General Learning Press, 1960.

[3] Bandura, A. Exercise of Personal and Collective Efficacy in Changing Societies. New York : Cambridge University Press, 1995. DOI: 10.1017/CBO9780511527692

[4] Jing, B. Social learning and dynamic pricing of durable goods. // Marketing Science. 30, 5(2011), pp. 851-865. DOI: 10.1287/mksc.1110.0649

[5] Tian, C.; Zhu, Q.; Qin, Z. Y.; Li, P. Query Services Ranking for Recommendation Based on Review Analysis. // Journal of Chinese Computer Systems. 32, 9(2011), pp. $1740-1746$

[6] Lin, C.; Hu, J.; Kong, X. Z. Survey on Models and Evaluation of Quality of Experience. // Chinese Journal of Computers. 35, 1(2012), pp. 1-15. DOI: 10.3724/SP.J.1016.2012.00001

[7] Wu, J. P.; Hu, S. Q. Analysis of Social Capital Based on Non-Complete Information. // Economy and Management Review. 12, 3(2012), pp. 22-28.

[8] Cao, X. H.; Cai, L.; Miao, S. J. Research on the mimetic entrepreneurial decision-making mechanism based on the hi-tech industrial cluster. // Studies in Science of Science. 26, 4(2008), pp. 739-748.

[9] Bass, F. M. A New Product Growth Model for Consumer Durables. // Management Science. 50, 12(2004), pp. 18331840. DOI: $10.1287 / \mathrm{mnsc} .1040 .0300$
[10] Bass, F. M. The Relationship between Diffusion Rates, Experience Curves, and Demand Elasticities for Consumer Durable Technological Innovations. // The Journal of Business. 53, 3(1980), pp. 51-67. DOI: 10.1086/296099

[11] Tseng, F. M.; Hu, Y. C. Quadratic-Interval Bass Model for New Product Sales Diffusion. // Expert Systems with Applications. 36, 4(2009), pp. 8496-8502. DOI: 10.1016/j.eswa.2008.10.078

[12] Hsiao, J. P.; Jaw, C.; Huan, T. C. Information Diffusion and New Product Consumption: A Bass Model Application to Tourism Facility Management. // Journal of Business Research. 62, 7(2009), pp. 690-697. DOI: 10.1016/j.jbusres.2008.08.002

[13] Cai, Y. P.; Huang, G. H.; Yang, Z. F.; Lin, Q. G.; Tan, Q. Development of An Optimization Model for energy Systems Planning in the Region of Waterloo. // International Journal of Energy Research. 32, 11(2008), pp. 988-1005. DOI: $10.1002 /$ er.1407

[14] Huang, C. Y.; Chen, H. N. Global Digital Divide: A Dynamic Analysis Based on the Bass Model. // Journal of Public Policy \& Marketing. 29, 2(2010), pp. 248-264. DOI: 10.1509/jppm.29.2.248

[15] Xu, X. H.; Song, Q. Z. Forecasting for Products with Short Life Cycle Based on Improved Bass Model. // Industrial Engineering and Management. 15, 5(2007), pp. 27-31.

[16] Phillips, F. On S-curves and Tipping Points. // Technological Forecasting and Social Change. 74, 6(2007), pp. 715-730. DOI: 10.1016/j.techfore.2006.11.006

[17] Paul, D. Measuring the Value of Electronic Word of Mouth and its Impact in Consumer Communities. // Journal of Interactive Marketing. 21, 2(2007), pp. 63-79. DOl: 10.1002/dir.20078

[18] Yong, P. H. Innovation Diffusion in Heterogeneous Populations: Contagion, Social Influence, and Social Learning. // The American Economic Review. 99, 5(2009), pp. 1899-1924. DOI: 10.1257/aer.99.5.1899

[19] Kiss, C.; Bichler, M. Identification of InfluencersMeasuring Influence in Customer Networks. // Decision Support Systems. 46, 1(2008), pp. 233-253. DOI: 10.1016/j.dss.2008.06.007

[20] Peres, R.; Muller, E.; Mahajan, V. Innovation Diffusion and New Product Growth Models: A Critical Review and Research Directions. // International Journal of Research in Marketing. 27, 2(2010), pp. 91-106. DOI: 10.1016/j.jiresmar.2009.12.012

[21] Rogers, E. The Diffusion of Innovations. New York: The Free Press, 2003.

[22] Richter, H.; Yang, S. Learning behavior in Abstract Memory Schemes for Dynamic Optimization Problems.// Soft Computing. 13, 3(2009), pp. 1163-1173. DOI: 10.1007/s00500-009-0420-6

[23] Newman, M. Scientific Collaboration Networks: Network Construction and Fundamental Results. // Physics Review E. 64, 1(2001), pp. 1-8. DOI: 10.1103/physreve.64.016131

[24] Parkhe, A.; Wasserman, S.; Ralston, D. A. New Frontiers in Network Theory Development. // Academy of Management Review. 31, 3(2006), pp. 560-568. DOI: 10.5465/AMR.2006.21318917

[25] Mahajan, V.; Schoeman, M. F. Generalized Model for the Time Pattern of the Diffusion Process. // Engineering Management, IEEE Transactions. 1(1977), pp. 12-18. DOI: 10.1109/TEM.1977.6447316

[26] Mansfield, E. Technical Change and the Rate of Imitation. // Econometrica: Journal of the Econometric Society. 29, 4(1961), pp. 741-766. DOI: 10.2307/1911817

[27] Chatterjee, R. A.; Eliashberg, J. The Innovation Diffusion Process in a Heterogeneous Population: A Micromodeling Approach. // Management Science. 36, 9(1990), pp. 10571079. DOI: $10.1287 / \mathrm{mnsc} .36 .9 .1057$ 
[28] Song, I.; Chintagunta, P. A Micromodel of New Product Adoption with Heterogeneous and Forward Looking Consumers: Application to the Digital Camera Category. // Quantitative Marketing and Economics. 1, 4(2003), pp. 371-407. DOI: 10.1023/B:QMEC.0000004843.41279.f3

[29] Duan, M. S.; Zhang, X. L.; Gu, S. H. Innovation Diffusion Model Based on Micro Decision Process. // System Engineering Theory and Practice. 21, 6(2011), pp. 46-51.

[30] Bemmaor, A.; Lee, Y. The Impact of Heterogeneity and IllConditioning on Diffusion Model Parameter Estimates. // Marketing Science. 21, 3(2002), pp. 209-220. DOl: 10.1287/mksc.21.2.209.151

[31] Wang, P.; Sun, H. The Diffusion Model of Partial Total Substitution Creative Products. // System Engineering. 23, 9(2005), pp. 33-36.

[32] Zhong, J.; Wu, S. Z.; Zhang, B. A Case Study of High-Tech Firms' Learning beyond Boundaries. // Studies in Science of Science. 26, 3(2008), pp. 578-583.

[33] Lai, H. B.; Wang, J. L.; Cheng, J. X. The Relation Study of the Risk, Knowledge and Reputation of Networks with the Learning cross the Boundaries of Enterprise Networks. // Science \& Technology Progress and Policy. 29, 8(2012), pp. 130-134.

[34] Watts, D. J.; Strogatz, S. H. Collective Dynamics of Small World Networks. // Nature. 393, 4(1998), pp. 440-442. DOI: $10.1038 / 30918$

[35] Barabasi, A. Scale-Free Networks: A Decade and Beyond. // Science, 325, 7(2009), pp. 412-413. DOI: 10.1126/science. 1173299

[36] Zhuang, X. T.; Huang, W. Q. Study on Financial Innovation Diffusion Based on Consumer Network.// Journal of Management Sciences. 12, 3(2009), pp. 132-141.

[37] Jing, B. Exogenous Learning, Seller-Induced Learning, and Marketing of Durable Goods. // Management Science. 52, 10(2011), pp. 1788-1801. DOI: $10.1287 /$ mnsc.1110.1355

[38] Newman, M. Scientific Collaboration Networks: Network Construction and Fundamental Results. // Physics Review E. 64, 1(2001), pp. 1-8. DOI: 10.1103/physreve.64.016131

\section{Author's address}

Bin Du, PhD, Associate Professor

School of Information Management, Jiangxi University of Finance and Economics

Yuping West Street 556\#, (Mailuyuan District), Nanchang, Jiangxi, China, 330032

E-mail: dubin@jxufe.edu.cn 